\title{
PENGARUH TERAPI SUPORTIF KELOMPOK TERHADAP PENGETAHUAN KELUARGA MELATIH PERAWATAN DIRI ANAK TUNAGRAHITA DI SLB NEGERI 01 JAKARTA
}

\author{
*Ni Bodro Ardi ${ }^{1}$, **Suhendar Sulaeman, ***Nyimas Heny Purwanti \\ Program Studi S1 Keperawatan, STIKes Widya Dharma Husada Tangerang \\ Jalan Pajajaran No1, Pamulang Tangerang Selatan Banten \\ nibodroardi@wdh.ac.id
}

\begin{abstract}
ABSTRAK
Salah satu gangguan pada anak tunagrahita adalah pemenuhan kebutuhan perawatan diri. Peran keluarga merawat anak tunagrahita akan berdampak pada tingkat kemandirian perawatan dirianak. Tujuan penelitian ini untuk mengetahui pengaruh terapi suportif kelompok terhadap pengetahuan dan motivasi keluarga dalam melatih perawatan dirianak tunagrahita di SLB Negeri 01 Jakarta. Desain penelitian ini adalah Quasi Experimental dengan rancangan non randomized without control pretest-posttest design dengan jumlah sampel 64 responden secara purposive sampling. Responden dibagi dalam 4 kelompok yang mendapatkan terapi suportif kelompok sebayak 5 kali intervensi, dengan menggunakan video dan praktek mandiri. Hasil penelitian ini menunjukkan terjadi peningkatan rata-rata skor pengetahuan dan motivasi pada ke empat kelompok $(\mathrm{p}=<0,05)$. Sehingga dapat disimpulkan bahwa ada pengaruh terapi suportif terhadap pengetahuan orang tua terhadap perawatan diri anak tunagrahita. Pemberian terapi suportif kelompok dapat diterapkan sebagai salah satu intervensi keperawatan untuk meningkatkan pengetahuan keluarga dalam merawat diri anak tunagrahita.
\end{abstract}

Kata Kunci: terapi suportif kelompok, perawatan diri, tunagrahita, pengetahuan.

\begin{abstract}
One of the disturbance in mentally retarded children is fulfilling the needs of selves-care. The family role in taking care the mentally retarded children will impact on the children selves-care indepence. The objective of this study is to determine the effect of group suportive Therapy on knowledge family in training mentally retarded children in SLB Negri 01 Jakarta. The design used in this study is Quasi Experiment with nonrandomized design without control pretest-postest design with number of samples is 64 respondents of purposive sampling, who are devided into 4 groups. The groups will obtain supportive group therapy intervention 5 times using video and practice independently. The result of the study shows the increasing scores rate of knowledge and motivation in the four groups $(p=<0,05)$, so it can be concluded that there is an effect of of supportive therapy on knowledge parent towards mentally retarded children selves-care. The giving of group supportive therapy can be one of the nursing intervention to improve knowledge family in taking care mentally retarded children.
\end{abstract}

Keywords : supportive therapy groups, self care, mentally retardation and knowledge 


\section{PENDAHULUAN}

Tunagrahita merupakan anak dengan fungsi intelektual yang rendah yaitu dibawah rata-rata, yang muncul bersamaan dengan kurangnya perilaku adaptif dan kemampuan beradaptasi (APA: 2000: Townsend, 2005). Ditinjau dari karakteristiknya tunagrahita mempunyai karakteristik yaitu IQ yang rendah, kurang tanggap, penampilan fisiknya kurang proporsional, perkembangan bicara terhambat karena bahasanya terbatas, serta tingkat ketergantungan yang tinggi dalam perawatan dirinya. Anak tunagrahita mempunyai keterbatasan kemampuan diantaranya kemampuan komunikasi, perawatan diri, keselamatan, kesehatan, kemampuan akademik rendah, masalah sosial dan pekerjaan (Yayasan Pendidikan Dwituna Rawinala, 2008).

Masalah yang sering muncul pada anak tunagrahita yaitu hambatan dalam perkembangan sosialnya antara lain, gangguan komunikasi, ketidakmampuan memenuhi kebutuhan diri, gangguan emosional dan gangguan tingkah laku. Masalah perawatan diri pada anak tunagrahita berdampak pada perkembangan dirinya.Untuk perawatan diri seperti; makan, mandi, toilet training, berhias dan memakai pakaian

harus bisa dilakukan secara mandiri tanpa bantuan orangtua. Apabila anak tidak bisa memenuhi kebutuhan dirinya akan berdampak pada keluarga. Akibatnya hal ini akan terjadi timbal balik, anak mengalami kelambatan perkembangan karena orang tua berada dalam reaksi krisis emosi. Setiap anak, baik normal maupun tunagrahita, seharusnya memiliki kesempatan yang sama dalam hal pendidikan dan pengajaran. Hal tersebut menunjukkan bahwa orangtua sangat berperan penting terhadap proses pertumbuhan dan perkembangan anaknya, khususnya di dalam kemandirian anak untuk daily activities dan self care (Fadden, 1998, Wituk., 2000 dalam Chien, 2006).

Orangtua dengan anak tunagrahita, memiliki peran yaitu: mengajarkan anak tentang sosialisasi dan perawatan diri, memberikan konseling kepada anak, mengatur tingkah laku untuk menjalin hubungan dengan anak yang lain, mengasuh saudara kandung yang tidak berkebutuhan khusus. Jadi salah satu upaya yang dapat dilakukan dalam memberdayakan keluarga dalam rangka melatih kemampuan perawatan diriadalah membantu keluarga 
meningkatkan kemampuan anak dengan cara memberi dukungan (Yayasan Pendidikan Dwituna Rawinala, 2008).

Penanganan perawatan diri akan meningkatkan kemandirian pada anak tunagrahita. Saat ini penatalaksanaan yang efektif untuk memenuhi perawatan diri pada anak tunagrahita adalah terapi suportif kelompok. Hasil penelitian Chien, dkk. (2006) mengenai hasil support group pada keluarga China dengan diagnose Skizofrenia menunjukkan bahwa Supportive Therapy (TS) memberi efek positif pada beban keluarga, fungsi klien, dan lamanya klien kembali ke RS. Selain itu, memberikan dampak pada perilaku keluarga selama 12 bulan lamanya setelah pemberian terapi. Hasil penelitian, Tati Hernawaty (2009), pengaruh terapi kelompok suportif berdampak secara signifikan terhadap kemampuan keluarga merawat klien gangguan jiwa di kelurahan Bubulak. Sementara ini, belum diketahui adanya penelitian yang menunjukkan manfaat terapi suportif kelompok pada orangtua dengan anak tunagrahita.

Pada saat ini penelitian terkait perawatan diri pada anak berkebutuhan khusus sudah banyak diteliti, namun khusus pada anak tunagrahita belum begitu banyak diteliti. Berdasarkan masalah diatas peneliti tertarik untuk melakukan penelitian tentang pengaruh terapi suportif kelompok terhadap pengetahuan keluarga melatih perawatan diri anak tunagrahita.

Tujuan dari penelitian ini adalah untuk mengetahui pengaruh terapi suportif kelompok terhadap pengetahuan keluarga melatih perawatan diri anak tunagrahita.

\section{METODE}

Penelitian ini merupakan penelitian quasy experimental dengan rancangan penelitian non equivalent without control group (non randomized without control group pretest-posttest. Dalam penelitian ini menggunakan responden dibagi menjadi 4 kelompok yaitu pendidikan rendah, pendidikan tinggi, pendapatan rendah, dan pendapatan tinggi.

$$
\text { Pengambilan sampel }
$$
menggunakan purposive sampling dan masing-masing kelompok terdiri dari 16 responden. Adapun kriteria inklusi pada penelitian ini adalah bertanggung jawab terhadap anak dan tinggal bersama anak tunagrahita, orang tua anak tunagrahita, dapat membaca dan 
menulis dan berkomunikasi secara verbal, serta bersedia menjadi responden dalam penelitian.

Alat pengumpulan data menggunakan kuesioner pengetahuan dengan nilai alpha cronchbach $=0,878$ dan kuesioner motivasi dengan nilai alpha cronchbach $=0,875$. Analisa data menggunakan SPSS 20 dengan uji paired $t$ test untuk data yang berdistribusi normal dan wilcoxon untuk data yang tidak berdistribusi normal.

\section{HASIL}

Hasil penelitian disajikan dalam bentuk analisa univariat (karakteristik responden) dan analisa bivariat.

\section{Karakteristik responden}

Tabel 1.Distribusi responden berdasarkan karakteristik kelompok usia, jenis kelamin, agama, pendidikan, pekerjaan, pendapatan, dan hubungan dengan klien di SLB Negeri 01 JakartaApril-Mei 2017 (n=64)

\begin{tabular}{lcc}
\hline & Frekuensi & Persentase (\%) \\
\hline Usia & 10 & 15,6 \\
a. 20-30 tahun & 28 & 43,8 \\
b. 31-40 tahun & 18 & 28,1 \\
c. 41-50 tahun & 8 & 12,5 \\
d. 51-60 tahun & 4 & \\
\hline Jenis kelamin & 60 & 6,3 \\
a. Laki-laki & & 93,8 \\
b. Perempuan & 61 & 95,3 \\
\hline Agama & 2 & 3,1 \\
a. Islam & 1 & 1,6 \\
b. Kristen protestan & & \\
c. Katolik & 27 & 42,2 \\
\hline Pendidikan & 37 & 57,8 \\
a. Pendidikan rendah & & \\
b. Pendidikan tinggi & 46 & 71,9 \\
\hline Pekerjaan & 6 & 9,4 \\
a. IRT & 10 & 3,6 \\
b. PNS & 2 & 54,7 \\
c. Wiraswasta & & 45,3 \\
d. Lainnya & 35 & 100 \\
\hline Pendapatan & 29 & \\
a. Pendapatan rendah & & \\
b. Pendapatan tinggi & 64 & \\
\hline Hubungan dengan klien & & \\
a. Orang tua kandung & & \\
\hline
\end{tabular}


Berdasarkan hasil analisis diatas menunjukkan karakteristik responden berdasarkan usia didapatkan dari 64 responden sebagian besar berusia 31-40 tahun yaitu 28 (43,8\%). Sedangkan karakteristik responden berdasarkan jenis kelamin didapatkan bahwa dari 64 orang responden sebagian besar berjenis kelamin perempuan yaitu 60 orang $(93,8 \%)$.

Tabel diatas menunjukkan karakteristik responden berdasarkan agama didapatkan bahwa dari 64 responden sebagian besar adalah islam yaitu 61 orang $(95,3 \%)$. Distribusi responden berdasarkan karakteristik pendidikan didapatkan dari 64 responden sebagian besar responden berpendidikan tinggi yaitu 37 orang $(57,8 \%)$. Karakteristik responden berdasarkan pekerjaan didapatkan bahwa dari 64 responden sebagian besar responden bekerja sebagai IRT yaitu 46 orang $(71,9 \%)$. Sedangkan karakteristik responden berdasarkan hubungan dengan klien didapatkan bahwa dari 64 orang responden seluruh responden memiliki hubungan dengan klien $(100 \%)$.

\section{Karakteristik responden berdasarkan mual dan muntah}

Tabel 2. Rata-rata skor pengetahuan responden sebelum intervensi terapi suportif di SLB Negeri 01 Jakarta April-Mei 2017 (n=64)

\begin{tabular}{lllll}
\hline Variabel & Mean & SD & MIN-MAX & $95 \%$ CI \\
\hline Pengetahuan & 63,56 & 7,502 & $45-80$ & $61,69-65,44$
\end{tabular}

Berdasarkan tabel 5.2 diatas estimasi interval $(95 \%$ CI $)$ dapat didapatkan bahwa rata-rata skor disimpulkan bahwa rata-rata skor pengetahuan responden 63,56 dengan pengetahuan berada pada rentang 61,69standar deviasi 7,502. Pengetahuan 65,44. minimal 45 dan maksimal 80. Hasil 
Tabel 5.3. Perbedaan rata-rata skor pengetahuan sebelum dan sesudah intervensi terapi suportif pada kelompok I, II, III, dan IV di SLB Negeri 01 Jakarta April-Mei 2017 $(\mathrm{n}=16)$

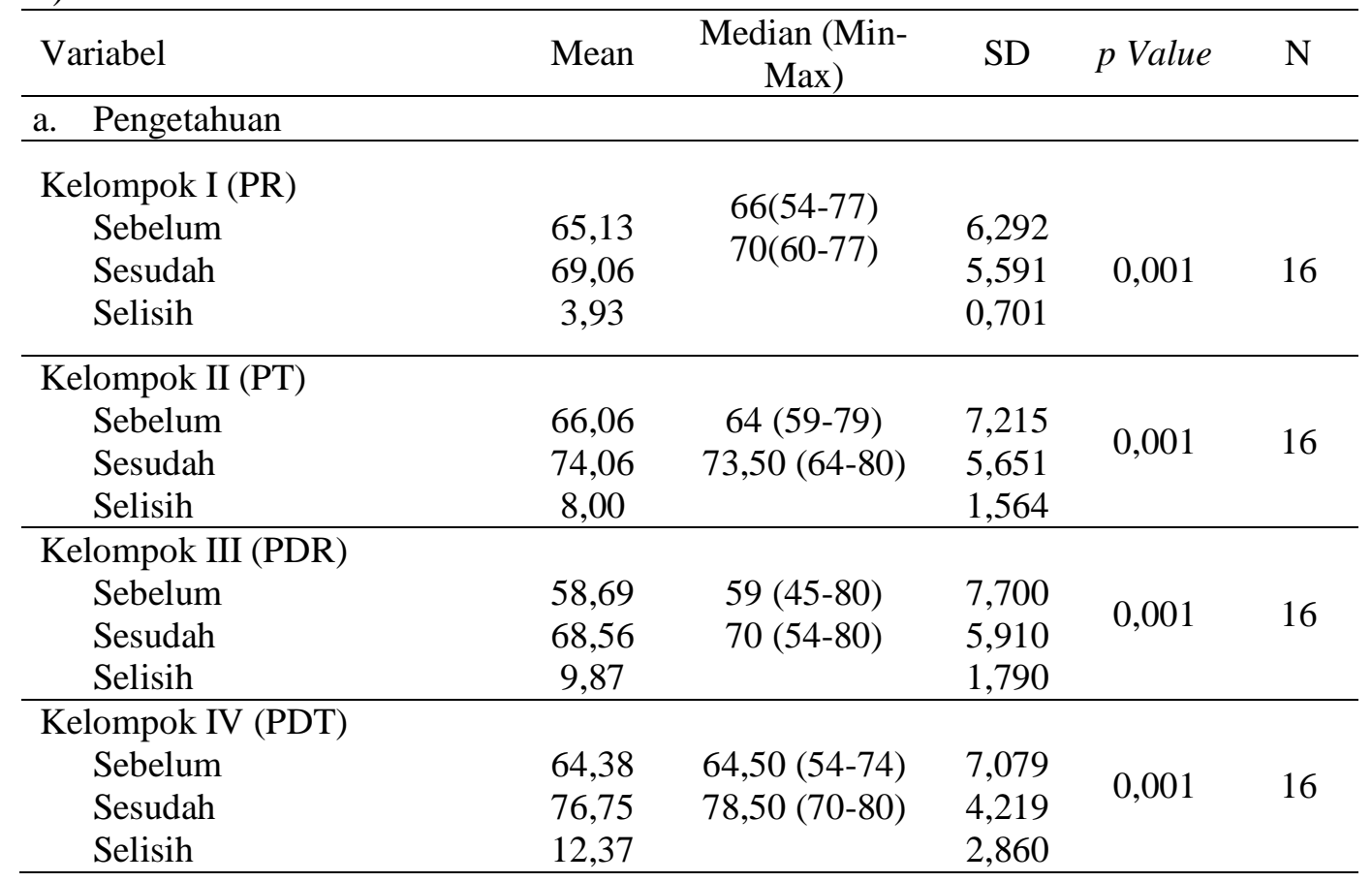

Berdasarkan tabel 5.3 menunjukkan bahwa pada kelompok berpendidikan rendah terjadi perubahan rata-rata skor pengetahuan antara sebelum dengan nilai rata-rata 65,13 dan sesudah $(68,06)$ diberikan terapi suportif. Nilai rata-rata skor pengetahuan naik sebesar 3,93. Peningkatan skor pengetahuan ini bermakna secara statistik dengan nilai $\mathrm{p}=0,001$ yang berarti bahwa ada pengaruh yang signifikan pemberian terapi suportif pada kelompok pendidikan rendah terhadap pengetahuan dalam perawatan diri anak tuna grahita.
Pada kelompok dengan pendidikan tinggi juga terjadi peningkatan rata-rata skor pengetahuan dari 66,06 menjadi 74,06. Nilai selisih skor pengetahuan antara sebelum dan sesudah diberikan terapi suportif adalah 8,00. Peningkatan skor pengetahuan ini juga bermakna secara statistik dengan nilai $\mathrm{p}=0,001$ yang berarti bahwa ada pengaruh yang signifikan pemberian terapi suportif pada kelompok pendidikan tinggi terhadap pengetahuan dalam perawatan diri anak tuna grahita.

Tabel diatas juga menjelaskan bahwa pada kelompok yang berpendapatan rendah juga terjadi 
peningkatan skor pengetahuan dari 58,69 menjadi 68,56. Nilai selisih skor pengetahuan antara sebelum dan sesudah diberikan terapi suportif adalah 9,87. Peningkatan skor pengetahuan ini juga bermakna secara statistik dengan nilai $\mathrm{p}=$ 0,001 yang berarti bahwa ada pengaruh yang signifikan pemberian terapi suportif pada kelompok pendapatan rendah terhadap pengetahuan dalam perawatan diri anak tuna grahita.

$$
\text { Pada kelompok dengan }
$$
pendapatan tinggi juga terjadi peningkatan rata-rata skor pengetahuan dari 64,38 menjadi 76,75 . Nilai selisih skor pengetahuan antara sebelum dan sesudah diberikan terapi suportif adalah 12,37. Peningkatan skor pengetahuan ini juga bermakna secara statistik dengan nilai $\mathrm{p}=0,001$ yang berarti bahwa ada pengaruh yang signifikan pemberian terapi suportif pada kelompok pendapatan tinggi terhadap pengetahuan dalam perawatan diri anak tuna grahita.

\section{PEMBAHASAN}

1. Usia

Hasil penelitian menunjukkan ada kontribusi usia orangtua dalam memberikan latihan perawatan diri. Mayoritas orang tua yang merawat anak tunagrahita berada pada usia produktif.
Menurut Siagian (2012), semakin lanjut usia seseorang semakin meningkat pula kedewasaan teknis dan tingkat kedewasaan psikologisnya yang menunjukkan kematangan jiwa, dalam arti semakin bijaksana, mampu berpikir secara rasional, mengendalikan emosi dan bertoleransi terhadap orang lain. Stuart dan Laraina (2005) menyatakn usia berhubungan dengan pengalaman seseorang dalam menghadapi berbagai macam stressor, kemampuan memanfaatkan sumber dukungan dan ketrampilan dalam mekanisme koping.

2. Jenis kelamin

Beberapa budaya di Indonesia masih menganggap bahwa tugas pemberi perawatan pada anak tunagrahita murni menjadi tanggung jawab seorang perempuan. Lindahl (1997 dalam Widyanti, 2009) mengatakan bahwa kebanyakan perawatan informal dalam konteks keluarga dilakukan oleh seorang istri, anak perempuan, atau menantu perempuan. Peran caregiver yang dijalankan perempuan dapat menyebabkan kesejahteraan psikologis perempuan menjadi rentan. Stres caregiver lebih banyak dialami perempuan, dimana perempuan lebih 
merasa terbebani dalam hal fisik, emosional, dan finansial.

\section{Pendidikan}

Pendidikan adalah salah satu usaha untuk mengembangkan kepribadian dan kemampuan di dalam dan di luar sekolah, dan akan berlangsung seumur hidup (long life education) (Tarwoto \& Wartonah, 2010). Pendidikan merupakan faktor yang berkontribusi dalam pengetahuan dan dalam merawat diri anak tunagrahita. Seseorang dengan pendidikan tinggi akan mampu mengelola, mengatasi, dan menggunakan koping efektif dan konstruktif daripada seseorang yang memiliki pendidikan rendah (Notoatmodjo, 2007; Saddock \& Saddock, 2007).

Pendidikan menjadi suatu tolak ukur kemampuan seseorang dalam berinteraksi dengan orang lain secara efektif (Stuart \& Laraia, 2008).

Menurut peneliti bahwa pendidikan sangatlah penting dalam proses penerimaan informasi kesehatan. orang tua yang mempunyai anak tunagrahita. Pendidikan tinggi memiliki kemampuan kognitif yang baik untuk menerima, mencari informasi tentang perawatan diri anak, sehingga pasien dengan pendidikan tinggi akan memiliki pengetahuan yang tinggi terhadap perawatan diri anak tunagrahita.

\section{Pendapatan}

Hasil penelitian ini didapatkan sebagian besar responden memiliki pendapatan rendah yaitu sebanyak 35 orang. Penelitian yang dilakukan oleh Gulseren, dkk (2010) yang menyimpulkan bahwa terdapat hubungan antara besar penghasilan sebagai indikator status sosial ekonomi dengan beban dan tingkat ansietas keluarga. Beberapa penelitian lainnya turut mendukung bahwa faktor sosial ekonomi rendah, lebih banyak dialami keluarga dengan anak tunagrahita dibandingkan pada tingkat sosio ekonomi tinggi. Hal ini berpengaruh terhadap kondisi kehidupan yang berada dalam kemiskinan, seperti tidak memadainya fasilitas untuk akomodasi, biaya untuk menyekolahkan anak dalam sekolah khusus, nutrisi yang tidak adekuat bagi anak, rendahnya pemenuhan kebutuhan perawatan untuk anak, sedikit sekali sumber untuk mengatasi situasi stres, dan perasaan tidak berdaya (Tsai \& Wang, 2008; Hassall, Rose \& McDonald, 2005; Emerson, 2003).

Hasil penelitian menunjukkan bahwa ada perbedaan yang signifikan 
pada nilai pengetahuan setelah diberikan terapi suportif kelompok. Nilai perubahan skor paling tinggi adalah pada kelompok yang memiliki pendidikan tinggi dan pendapatan tinggi. Hal ini menunjukkan bahwa dari keempat kelompok tersebut, masingmasing kelompok terjadi peningkatan pengetahuan pada keluarga dengan anak tunagrahita.

Peningkatan pengetahuan pada keluarga dengan anak tunagrahita pada penelitian ini sejalan dengan konsep Self care. Hasil tersebut sesuai dengan pendapat Heller, dkk ( 1997, dalam Chien, Chan, dan Thomshon, 2006) bahwa dukungan kelompok dalam hal ini melalui terapi suportif kelompok berhubungan dengan peningkatan fungsi secara psikologis dan mengurangi beban keluarga. Sedangkan mutual support yaitu dukungan yang bermanfaat adalah suatu proses partisipasi dimana terjadi aktifitas berbagai pengalaman situasi dan masalah yang difokuskan pada prinsip memberi dan menerima. Terapi suportif kelompok mengakomodasi prinsip mutual support ini sehingga, keluarga dapat mengembangkan pengetahuan dan mengaplikasikan perawatan diri pada anak tunagrahita. Proses pendampingan perawat didalam melakukan terapi suportif kelompok sejalan dengan peran perawat sebagai salah satu tenaga kesehatan, karena perawat mempunyai tanggung jawab dan peran dalam meningkatkan status kesehatan masyarakat, yang meliputi promotif, preventif, kuratif dan rehabilitatif.

Pengetahuan meningkat maka perawatan diri pada anak tunagrahita juga akan meningkat. Ketrampilan psikomotor orangtua dalam melatih perawatan diri perlu dilatih secara terus menerus sehingga didapatkan hasil yang optimal. Hasil penelitian ini didukung oleh penelitian yang dilakukan Sri Hunun (2012) yang bertujuan membuktikan pengaruh terapi suportif kelompok terhadap pengetahuan anak tunagrahita.

Penelitian ini menyatakan bahwa proses terapi suportif kelompok yang diberikan pada partisipan mampu membantu keluarga mendampingi anaknya yang berkebutuhan khusus. Didalam terapi ini aspek edukasi yang ada didalam terapi suportif kelompok adalah pada kegiatan diskusi. Hal ini dapat dilihat dari peningkatan skor berkaitan pada pengetahuan keluarga secara bermakna setelah diberikan terapi 
suportif kelompok pada empat kelompok intervensi.

Tehnik terapi suportif kelompok dipilih sebagai bentuk intervensi untuk mengatasi masalah ketidakmandirian dalam perawatan diri pada anak tunagrahita. Penggunaan terapi ini memberi kesempatan kepada anggotanya untuk saling berbagi pengalaman, saling membantu satu dengan lainnya, untuk menemukan cara menyelesaikan masalah dan mengantisipasi masalah yang akan dihadapi dengan mengajarkan cara yang efektif mengajarkan perawatan diri anak dan saling memberikan penguatan untuk membentuk perilaku yang adaptif. Dari analisis peneliti kemampuan pengetahuan pada keempat kelompok meningkat secara bermakna setelah dilakukan terapi suportif kelompok.

Selain hal tersebut, menurut pendapat peneliti, perbedaan nilai ratarata tersebut disebabkan karena adanya keberadaan komite orang tua di SLB Negeri 01 Jakarta. Komite orang tua merupakan wadah berkumpulnya beberapa orang tua di SLB Negeri 01 Jakarta.Kegiatan komite orang tua di SLB ini berjalan secara rutin dan sudah terjadwal dan orang tua biasanya memanfaatkan kegiatan tersebut sebagai media untuk bertukar pendapat dan berbagi pengalaman dalam merawat anak tunagrahita.

Melalui penelitian ini dapat mengaplikasikan teori Self Care yang dikembangkan oleh Orem bahwa anak melewati tahap diantaranya: jika ada self care deficit, self care agency dan self care theraupetic maka keperawatan akan di berikan. Pada penelitian ini peran perawat dalam memberikan bantuan kepada keluarga dengan anak tunagrahita bertujuan memandirikan individu atau keluarga dalam memenuhi aktivitas hidup sehari-hari untuk memenuhi perawatan dirinya. Pada anak dengan tunagrahita pemenuhan kebutuhan perawatan diri, perawat perlu membantu anak supaya terpenuhinya kebutuhan perawatan dirinya secara mandiri dan tidak terlalu bergantung dengan bantuan orangtua. Hal ini sesuai dengan prinsip self care yang dikemukakan oleh Orem. Berdasarkan teori ini peran perawat adalah memandirikan setiap individu meskipun dengan keterbatasan sehingga bisa memenuhi kebutuhan perawatan dirinya. Maka dengan intervensi terapi suportif kelompok ketiga tahapan Orem dapat tercapai, digambarkan anak tunagrahita dengan 
gangguan komunikasi, sehingga tidak mampu memenuhi kebutuhan dirinya, gangguan emosional dan gangguan tingkah laku mengalami Self care deficit Sehingga disitulah peran perawat mendidik orang tua atau keluarga mengajarkan tentang perawatan diri di tahap Nursing system sehingga diharapkan melalui keluarga perawatan diri anak tunagrahita terpenuh dan meningkati.

Friedman dkk, (2003) berpendapat kemampuan perawat memberikan asuhan keperawatan keluarga, sehingga memandirikan anggota keluarga yaitu anak tunagrahita agar tercapai peningkatan kesehatan seluruh anggota keluarganya dan keluarga mampu mengatasi masalah kesehatan. Kurangnya pengetahuan keluarga yang adekuat mengakibatkan kurangnya motivasi dalam merawat diri anaknya.

Hasil penelitian menunjukkan bahwa ada perubahan signifikan pada nilai pengetahuan keluarga setelah diberikan terapi suportif kelompok pendidikan tinggi dan rendah berarti bahwa keluarga memahami tentang perawatan diri anak tunagrahita. Hal ini menunjukkan bahwa dari ke empat kelompok tersebut masing-masing kelompok terjadi peningkatan skor pengetahuan.

Menurut pendapat peneliti, peningkatan nilai disebabkan karena adanya pemberian terapi suportif dan jadwal ramah tamah pada orangtua sudah tersusun sesuai dengan jadwal. Para partisispan sangat antusias mengikuti jalannya terapi. Kegiatan terapi inilah di manfaatkan oleh para orangtua untuk saling bercerita, berbagi pengalaman, serta saling berkonsultasi tentang tingkah laku anak tunagrahita dirumah dengan harapan dapat informasi tentang perawatan diri anak tunagrahita.

Kesempatan untuk melakukan demonstrasi melatih perawatan diri perlu dilakukan secara terus menerus dan berulang-ulang sehingga didapat hasil yang optimal, dan untuk itu perlu upaya pengulangan orangtua pada anaknya sehingga semua anggota keluarga mempunyai kesempatan yang sama. Heward, (2002) memperkuat pandangan ini dengan mengatakan bahwa orangtua merupakan orang yang paling penting dalam program intervensi dini untuk mengajar dan melatih anak dalam keterbatasannya dan hal ini dilakukan secara terstuktur dan terprogram.

Ketrampilan yang dilatih melalui praktik secara berulang-ulang akan 
menjadi kebiasaan atau otomatis dilakukan dan latihan yang dilakukan berulang-ulang akan memberikan pengaruh yang sangat besar pad kemahiran ketrampilan. Lebih lanjut dalam penelitian dilaporkan bahwa pengulangan saja tidak cukup menghasilkan kemampuan yang meningkat, namun diperlukan unpan balik yang relewan yang berfungsi untuk memantapkan kebiasaan.

\section{KESIMPULAN DAN SARAN}

1. Ada perbedaan rata-rata pengetahuan keluarga dalam melatih perawatan diri anak tunagrahita sebelum dan sesudah diberikan terapi suportif kelompok pendidikan rendah maupun tinggi di SLB Negeri 01 Jakarta (p value $<0,05)$ dengan nilai selisih 3,93 dan 8,00 .

2. Ada perbedaan rata-rata pengetahuan keluarga dalam melatih perawatan diri anak tunagrahita sebelum dan sesudah diberikan terapi suportif kelompok pendapatan rendah maupun tinggi di SLB Negeri 01 Jakarta ( $\mathrm{p}$ value $<0,05)$ dengan nilai selisih 9,87 dan 12,37

\section{DAFTAR PUSTAKA}

Appelbaum,A.H.(2005).Supportivethera py4.http://www.focus.psychiatryo nline.org/cgi, diperolehtanggal 2 Februari 2017
Ashman,A.,\&Elkins,J.(1998). Educatingchildrenwithspecialnee ds(3red.).Australia: Prentice Hall

Astati. (2003). Programkhususbinadiri,pelatihan programgurukhususbagiguru. SLB/SLB tingkatnasional. Depdiknas - Direktorat PLB

Bedell, J.R., dkk. (1997).Current approaches to assessment and treatment of person with serious mental illness, 70, http://www.psychosocial.com/ research/current.html, diperoleh tanggal 2 Februari 2017.

Boyd,M.A., \&Nihart, MA. (1998).Psychiatric nursing contemporary practise, Philadelphia: Lippincott

Brooks,J. (2008). The process of parenting (7th ed.). New York : McGraw-Hill.

Chien,W.T.\&Wong,K.F.(2007).Af amilypsychoeducationgroupprogr amforchinese people with schizophrenia in Hong Kong. Psychiatric Services. Arlington. www.proquest.com.pqdauto.

Diperolehtanggal 2 Februari 2017

Chien, W.T., Chan, S.W.C., dan Thompson, D.R. (2006). Effects of a mutual support group for families of chinese people with schizophrenia: 18-Months followup. http://bjp.rcpsych.org, diperoleh tanggal 2 Februari 2017.

Cronbach, L.J. (1990). Essentials of psycological testing (5thed).New York:Hapercollinspublication 
Crews. N.J (2002). Bukupegangan guru untukanakcacat. Jakarta: Yayasan PendidikanDwitunaRawinala

Depkes

RI.

(2010). Risetkesehatandasar 2007. Jakarta.

BadanPenelitiandanPengembang anKesehatanRepublik Indonesia.

Hockenberry \& Wilson. (2009). Wong: Essentials of pediatric nursing 8 ed. Philadelphia: Mosby Elsevier

Kaplan, R.M. \& Dennis P.S. (2001). Psychological testing: principles, aplications, and issues (5th ed). California: Wadsworth / Thomson Learning.

Notoatmodjo,S. (2012). Metodologipenelitiankesehatan.J akarta : PT RinekaCipta.

Mangunsong,F.,dkk(1998).Psikologida npendidikananakluarbiasa.

Depok: LPSP3 UI

Rocland, L.H. (2003). Supportive therapy, New York : Oxford Publicity Partnership

Sadock BJ, Sadock VA. (2007). Kaplan \& Sadock's Synopsis of Psychiatry. Behavior Sciences/Clinical Psychiatry. 10
Santrock, J.W.(2006). Life-span developmant (10th edition). New York, Mc Grow Hill

Stuart,G.W.,andLaraia,M.T.(2005).Pri nciplesandpracticeof psychiatric nursing ( $7^{\text {th }}$ ed.). St. Louis : Mosby Year B.

Tomey, A. M. \&Alligood, M. R. (2010).Nursing theorist and their work $\left(6^{\text {th }}\right.$ edition).USA : Mosby Elsevier.

Townsend,C.M.(2005).Essentialsofpsyc hiatricmentalhealth nursing ( ${ }^{\text {th }}$ Ed.).Philadelphia: F.A. Davis Company.

Videbeck, SL. (2008). Buku ajar keperawatan jiwa. Jakarta: EGC

Wong. D., et al. (2009).Buku ajar keperawatan pediatric.(Edisi 6) Volume 2.Alihbahasa Hartono, A., Kurnianingsih, S. \&Setiawan.Jakarta : EGC

WHO.(2010).Spesialneedschildreen.htt p://www/who.int/mediacentre/. Diaksestanggal 15 Maret 2017.

YayasanPendidikanDwituna Rawinala. (2008). Lentera: light of the heart(vol.1,Issue 1). 